\title{
Bisexuality in Republican Rome and the Güevedoces of Salinas (Dominican Republic): The Search for a Retrospective Diagnosis
}

\author{
Mercedes López Perez* \\ Departamento de Enfermería, Universidad de Murcia, Spain
}

\begin{abstract}
The malformations of children and some disabilities, as well as strange natural phenomena, were considered by the Romans, especially in the Republican era, as wonders. The most striking example was the appearance of an androgynous or hermaphrodite, a human being who at birth had the monstrous appearance of having both sexes at the same time. The recommended rites or the atonement of the prodigy are the widest and most complete of the viri sacris faciundis school, which we know thanks to the Sibylline Books, the works of Titus Livius and Obsequens. Also, in the work of Diodorus of Sicily two cases of intersexuality are described, Heraides and Calo are two women who in adolescence or puberty undergo a genital transformation that ends up turning them into men.

The main objective of this work is to explain these prodigies according to the modern terminology of teratology through retrospective medical diagnosis, and for this we will include the studies of Imperato McGinley in the Dominican Republic. In this place there are frequent cases of girls who develop male genitals (güevedoces) during adolescence. The absence of male genitals at birth is due to a deficiency of an enzyme known as 5-alphareductase, which normally converts testosterone into dihydrotestosterone. The comparison and analysis of Roman sources with cases of transformations of adolescents in the town of Salinas (Dominican Republic) allows us to understand this phenomenon more broadly, as well as to deepen the characteristics of the population that inhabited the Italian Peninsula in Republican Era.
\end{abstract}

KEYWORDS: Hermaphrodite; Androgynous; Prodigy; Sibylline Books; Güevedoces; Roman Religion; Roman History; Procuratio; Decenviri

\section{METODOLOGY}

In the present work we have selected and analyzed the classic texts of Titus Livius, Obsecuens and Diodorus of Sicily to know the exact descriptions of cases of androgynous and / or hermaphrodites, we have also consulted the medical works that refer to this topic: Hippocratic Treaties. In order to find a possible retrospective diagnosis and understand the dynamics of Roman Republican society, we have compared it with similar cases in Salinas (Dominican Republic). This topic arouses great interest, as evidenced by the wide and varied historiography that we have briefly included in the discussion.

\section{INTRODUCTION}

\section{Sexual ambiguity in classical sources}

Ancient sources use several terms for the word hermaphrodite:

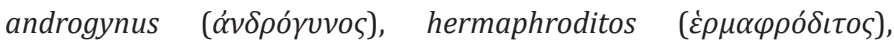

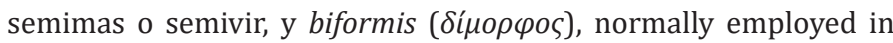

\begin{tabular}{|c|c|}
\hline \multirow{3}{*}{ 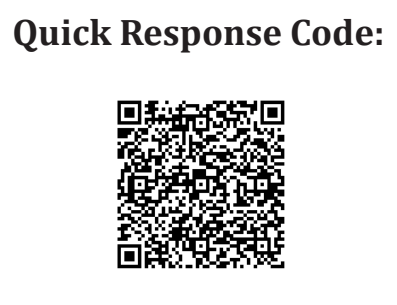 } & $\begin{array}{l}\text { Address for correspondence: Mercedes López Pérez, Universidad de Murcia, } \\
\text { Murcia, Spain }\end{array}$ \\
\hline & Received: March 02, $2020 \quad$ Published: March 12, 2020 \\
\hline & $\begin{array}{l}\text { w to cite this article: Mercedes LP. Bisexuality in Republican Rome and the Güevedoces } \\
\text { Salinas (Dominican Republic): The Search for a Retrospective Diagnosis. } 2020 \text { - 2(2) } \\
\text { JBS.ID.000152. DOI: } 10.38125 \text { /OAJBS.000152 }\end{array}$ \\
\hline
\end{tabular}


his masculine form. The oldest and most widely used form is that of androgynous (manwoman), used by Herodotus [1] to name the Enareos, effeminate men, whom, it seems and according to them, Aphrodite has given them the ability to guess. In the Hippocratic Treaties $[2,3]$ the term referring to the Anarieos is used, to refer to the Scythians, who's effeminate, say the Hippocratic doctors, occurs because of horse riding. It is in Livy where an androgynous is defined as a newborn with both sexes, considering hermaphrodite as a synonym for androgynous. Pliny defines hermaphrodite as one of the three types of semiviri, half-man, $\delta \dot{\mu} \mu о \rho \varphi о \varsigma$ is used by Diodorus [4] and Ovidy [5] to describe the bisexuality of Hermaphrodite after his union with Salmacis. There is no clear differentiation in the sources when using the terms androgynous and hermaphrodite, both are used interchangeably, or it is only indicated that it is of ambiguous sex. The sources demonstrate that the prodigies related to androgynous and / or hermaphrodites, as well as the births of children or animals with malformations, are the wonders most feared by the Romans. The first cases of prodigies related to androgynous are described by Tito Livio [6] and Obsecuens [7], who point out the prodigy and its procuratio: the decenviros or the aruspices were charged with the destruction of the child (in mare deportatus) and the celebration of rites to appease the wrath of the gods. The relevant thing about this type of prodigies is that they are the center of analysis of the Sibylline [8] rites and only this type of announcement was able to launch the entire decenviral mechanism.

\section{DISCUSSION}

The study of abnormal births and their relationship with the importance of fertility in the classical world is a thesis defended in the work of Delcourt [9] that we now consider a classic, and a starting point for studies on this subject. However, due to the focus of our study, we want to insist on the historiographic trend that attempts to analyze cases of bisexuality from a biological or biomedical approach. In 1996 Hansen [10], in his English edition of the work of Phlegon de Tralles, affirmed that the stories about bisexuality and sex change reflect an existing reality in the ancient world. Annie Allély [11], in her study on prodigies and malformations in the Republican era, affirms that hermaphrodite cases correspond to what we now call hermaphrodites and pseudo-hermaphrodites. George Androutsos [12] analyzes the cases of hermaphroditism in ancient literature and points to historical continuity on this topic, adding positive comments about the successes of current medical therapy. Hermaphroditism is a type of bisexuality that does not manifest itself in bone remains, but this has not prevented researchers such as Charlier [13] from developing a table with 22 possible diagnoses related to bisexuality.

\section{Girls who become boys in Salinas (Dominican Republic)}

In the small town of Salinas there are children whose penis grows at age 12. These young people are raised as girls until their genitals, hitherto hidden, come to light. The curious case of this region of the Dominican Republic was made public in the 70 s, when an American researcher traveled to the island to check those stories about girls who when they reached puberty became boys. Isolated cases were known in other parts of the world, but in this region, it is so common that they even have their own word, the güevedoces [14]. When Julianne Imperato McGinley [15] arrived in Salinas, she could immediately verify that she was facing a special case. In that town, one in 50 children ( $2 \%$ of the population) had been born without developing their male sexual organs. Obviously, that was not a statistical exception, so the researcher went to work until she reached a solution. The researcher concluded that the abnormal development of the genitals of these children during pregnancy is caused by a deficiency in an enzyme called 5-alphareductase. A low activity of this enzyme implies a lower production of dihydrotestosterone, a hormone that has an essential role in the formation of the male external genitalia. Having this deficiency, the male sexual organs do not fully develop during pregnancy and do not go outside, giving the feeling that they lack them and showing an image like lips and a clitoris. Only when entering puberty is when children begin to generate testosterone and then the change occurs. Deficiency of this enzyme is a common genetic condition in this part of the Dominican Republic, but very rare in other places. Deficiency of this enzyme is a common genetic condition in this part of the Dominican Republic, but very rare in others. sites. However, a similar case was discovered a few years later among members of the Sambia tribe in Papua New Guinea. In this case, these children are called "turnims," an acronym for the English expression "turn in man". The case of the turnims was thoroughly studied by Professor Gilbert Herdt, who conducted field studies for two decades and which were collected in the book.

The sexual culture of the Sambia. Unlike Imperato-McGinley, this researcher from the University of San Francisco studied the sociocultural and clinical aspects of gender formation among Sambia children, analyzing their evolution as they grew. One of the main differences observed in both cases is the difference in treatment towards children. The fact that they are small communities with little genetic variety has caused a prevalence of these births to be observed. This, in turn, has made both cultures accept to some extent the existence of three sexual categories: the male, the female and the pseudohermaphrodite. However, the way to address the issue is radically different between the two communities; however, the way to address the issue is radically different between the two communities. In Salinas, the birth of a pseudohermaphrodite is accepted naturally and the transition is celebrated as a special occasion, according to Dr. ImperatoMcGinley herself in her studies, published in 1974. However, the Sambia consider the turnims as imperfect men, being rejected and humiliated by their families and by the rest of society. As Professor Herdt has explained to the newspaper.es, "the subjects identified as male are treated differently and, for example, they are not allowed to marry a woman." The case of güevedoces and turnims highlighted the importance of both biological and sociocultural factors when developing gender expression.

\section{CONCLUSION}

The Roman texts that tell us and interpret, in their own way what the birth meant, or the appearance of a hermaphrodite or androgynous being, almost certainly reflect a reality: the existence of people with difficulties for sexual identification, being limited to two sexes. Classic literary and medical sources rationalize this diversity, also in its own way, through stories of sex change, through a pseudo-magical explanation. The ethnographic and biomedical studies of some current peoples, as we have seen in the case of the güevedoces of the town of Salinas, in the Dominican Republic show, that these are under circumstances very similar to those that could occur in certain italic regions, such as It is among others, to have small populations. The decrease of the population also entails a genetic limitation, which along with other variables can manifest itself in the difficulty of sexually identifying the individuals of their society, features that help us understand the Roman population of the republican era. 


\section{REFERENCES}

1. Schrader C (1979) Heródoto. Historia IV. Melpómene, Madrid: Gredos, Spain pp. 347.

2. López F, Jose A, García N, Elisa (1986) Tratados hipocráticos II, Madrid: Gredos, Spain 90: 80

3. Graumann AL (2013) Monstruous birth and retrospective diagnosis: The case of hermaphrodites in antiquity. In christian laes, CF Goodey, Lynn RM (eds.), Disabilities in Roman Antiquity. Mnemosyne Supplements V. 356, Brill, Leiden Boston, p.189.

4. Juan J, Torres E (2004) Diodoro de sicilia. Biblioteca Histórica (IV-VIII), Gredos, Madrid.

5. Ovidio, Metamorfosis 4: 274-388.

6. Villar VJA, Fernandez N (1993) Francisco javier tito livio. Historia de Roma desde su fundación. Libros XXVI-XXX y XXXI-XXXV, Gredos 177 y 183.

7. Villar V, Jose A (2008) Tito livio. Períocas de Oxirrinco. Fragmentos. Julio Obsecuente. Libro de los Prodigios, Gredos, Madrid.
8. Caerols P, José J (2011) Los libros sibilinos en la jistoriografía latina, madrid, p. 2.

9. Delcourt M (1986) Stérilités mystérieuses et naissances dans l' Antiquité Classique. Liege Presses Universitaires de Liège, Germany.

10. Hansen FW (1996) Phlegon de tralles' book of marvels. Translated with an introduction and commentary, University of Exeter, England p.124.

11. Allély A (2003) Les enfants malformés et considérés comme prodigia à Rome et en Italie sous la république. Revue des Etudes anciennes 105(1): 127-156.

12. Androutsos G (2006) "Hermaphroditism in greek and roman antiquity. Hormones (Athens) 5(3): 214-217.

13. Charlier $P$ (2008) Les monstres humanins dans l'Antiquité. Analyse paléopathologique, Paris, Fayard, pp. 267-280.

14. Teguayco $P(2015)$ Los güevedoces, las niñas que se convierten en niños a los 12 años.

15. Mc Ginley J (2014) “The effect of 5 5 -reductasa-2 deficiency on human fertility. Fertil Steril 101(2): 310-316. 